\title{
Sistem Pendukung Keputusan Kenaikan Jabatan Karyawan Dengan Simple Additive Weighting (SAW) Pada Dealer Mobil
}

\section{Decision Support System For Employee Promotion With Simple Additive Weighting} (SAW) At Car Dealers

\author{
Fransiska Prihatini Sihotang ${ }^{1}$, Ferent Michaela ${ }^{2}$ \\ ${ }^{1,2}$ Program Studi Sistem Informasi, STMIK GI MDP, Palembang \\ e-mail: ' fransiskaps@ mdp.ac.id*, ${ }^{2}$ ferentmichaela99@ mhs.mdp.ac.id
}

\begin{abstract}
Abstrak
Salah satu hal penting dalam pengelolaan SDM pada suatu perusahaan adalah penilaian kinerja. Penilaian kinerja karyawan sebagai salah satu kriteria naik jabatan dapat memacu semangat karyawan. Memiliki jumlah karyawan yang banyak membuat perusahana dealer mobil ABC mengalami kendala dalam melakukan penilaian terhadap karyawan. Hasil penilaian tidak transparan dan dilakukan secara sepihak dan tertutup, dan terdapat pula kriteria penilaian yang terkadang tidak diperhitungkan. Proses penilaian kinerja memakan waktu yang cukup lama dan hasilnya cenderung diragukan dan memunculkan rasa ketidakpuasan dari para karyawan. Peneliatian ini membuat sistem pendukung keputusan yang dapat membantu perusahaan dalam mengambil keputusan untuk kenaikan jabatan karyawan dengan menggunakan metode Simple Additive Weighting (SAW). Kriteria yang digunakan dalam penilaian adalah kriteria yang telah ditetapkan oleh perusahaan. Sistem ini dikembangkan berbasis website. Sistem dapat memudahkan proses perhitungan kinerja karyawan dari setiap manajer divisi secara otomatis dan terkomputerisasi, membantu perusahaan untuk mengambil keputusan secara objektif, serta membuat proses perhitungan penilaian kinerja karyawan menjadi transparan.
\end{abstract}

Kata kunci: SPK, kinerja karyawan, penilaian kinerja, naik jabatan, metode SAW

\begin{abstract}
One of the important things in Human Resource Management in a company is performance appraisal. Employee performance appraisal as one of the criteria for promotion can spur employee morale. Having a large number of employees makes the ABC car dealer company experience problems in assessing employees. The results of the assessment are not transparent and are carried out unilaterally and closed, and there are also assessment criteria that are sometimes not taken into account. The performance appraisal process takes a long time and the results tend to be questionable and lead to a sense of dissatisfaction from employees. This research creates a decision support system that can assist companies in making decisions for employee promotions using the Simple Additive Weighting (SAW) method. The criteria used in the assessment are criteria that have been established by the company. This system is developed web-based. The system can facilitate the process of calculating employee performance from each division manager automatically and computerized, helping companies to make decisions objectively, and making the process of calculating employee performance appraisals transparent.
\end{abstract}

Keywords: DSS, employee performance, performance assessment, job promotion, SAW method 


\section{PENDAHULUAN}

Perkembangan teknologi yang pesat semakin mendorong manusia untuk menggunakan bahkan menciptakan teknologi yang diharapkan dapat mempermudah pekerjaan ataupun peningkatan layanan kegiatan pada perusahaan. Salah satu kegiatan yang sering kita temui dalam perusahaan adalah pengambilan keputusan. Penggunaan teknologi dalam pengambilan keputusan membantu perusahaan untuk mendapatkan hasil yang lebih relevan dan dapat diterima oleh semua pihak. Sistem Pendukung Keputusan (SPK) atau (Decision Support System (DSS) merupakan sistem berbasis komputer yang interaktif yang dapat membantu serta meningkatkan kinerja seseorang dalam pengambilan keputusan dengan memanfaatkan data dan model yang ada [1].

Salah satu proses pengambilan keputusan dalam perusahaan yaitu penentuan ranking karyawan terbaik untuk kriteria naik jabatan. Sebagai bentuk apresiasi terhadap kinerja karyawan, perusahaan memberikan kenaikan jabatan terhadap karyawan yang memenuhi kriteria. Seperti yang diketahui, karyawan merupakan komponen terpenting yang mempengaruhi keberhasilan dalam suatu pekerjaan. Karyawan merupakan aset perusahaan dan pelaku utama produksi serta hasil pemasaran [2]. Implementasi sistem pendukung keputusan pernah diterapkan pada berbagai bidang, misalnya untuk menentukan tunjangan kinerja pegawai pada Kepolisian Resort Kota (POLRESTA) Jambi [3], pemilihan Siswa/i Kelas unggulan menggunakan metode AHP dan TOPSIS [4], pemilihan penyiar radio [5], proses penerimaan pegawai [6], dan lainnya.

Dealer mobil ABC merupakan salah satu perusahaan yang bergerak di bidang perdagangan penjualan mobil, khususnya dengan merek Toyota. Perusahan ini telah berdiri sejak tahun 2000 dan mempekerjakan 210 orang karyawan yang terbagi kedalam beberapa divisi, yaitu Sales, HRD, dan Manajer. Pada perusahan ini, proses penilaian kinerja karyawan untuk naik jabatan dilakukan setiap satu tahun sekali. Proses tersebut dilakukan mulai dari merekap data karyawan yang dilakukan oleh HRD hingga melakukan perhitungan penilaian. Adapun kriteria yang telah ditentukan dalam perhitungan penilaian, yaitu absensi, Tanggung Jawab, Kedisiplinan Kerja, Penyelesaian Kerja, dan Surat Peringatan.

Pada saat akan melakukan perhitungan penilaian, HRD meminta semua data karyawan dikumpulkan dari masing-masing divisi, lalu HRD merekap dan melakukan perhitungan satu persatu terhadap data yang telah dikumpulkan secara manual menggunakan aplikasi Mipengolah data. Hasil dari perhitungan tersebut diragukan keakuratannya karena banyaknya data karyawan yang harus direkap dan dihitung satu persatu menggunakan rumus/ formula oleh HRD. Proses perhitungan penilaian pun tidak transparan dikarenakan hasil penilaian tidak pernah dipublikasikan kepada masing-masing karyawan.

\section{METODE PENELITIAN}

Penelitian ini terdiri dari 4 langkah utama seperti yang tergambar pada diagram alir penelitian yang dapat dilihat pada Gambar 1 .

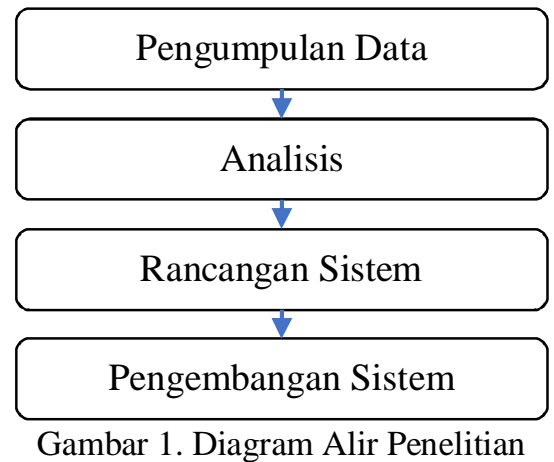




\subsection{Pengumpulan Data}

Pengumpulan data dilakukan dengan melakukan wawancara kepada pihak terkait pada dealer mobil ABC, observasi mengenai hal yang berhubungan dengan kenaikan jabatan karyawan, dan melakukan studi literatur pada penelitian yang terkait dengan sistem pendukung keputusan.

\subsection{Analisis}

Analisis permasalahan menggunakan kerangka PIECES yang terdiri dari Performance, Information, Economics, Control, Efeciency, dan Service dapat dilihat pada Tabel 1.

Tabel 1. Hasil Analisis Permasalahan menggunakan PIECES

\begin{tabular}{|c|c|l|}
\hline No. & PIECES & \multicolumn{1}{|c|}{ Permasalahan } \\
\hline 1. & Performance & $\begin{array}{l}\text { Hasil perhitungan terhadap penilaian kinerja karyawan diragukan keakuratannya dikarenakan } \\
\text { semua data tersebut harus diinput dan dihitung satu persatu oleh HRD secara manual. }\end{array}$ \\
\hline 2. & Information & $\begin{array}{l}\text { Informasi yang diterima oleh karyawan mengenai hasil penilaian kinerja karyawan tidak } \\
\text { transparan dan kurang akurat, dikarenakan terdapat kriteria seperti Surat Peringatan (SP) yang } \\
\text { seringkali tidak digunakan. }\end{array}$ \\
\hline 3. & Economic & $\begin{array}{l}\text { Perhitungan penilaian terhadap kinerja karyawan harus dilakukan satu persatu yang } \\
\text { membutuhkan waktu yang lama dan biaya yang cukup mahal. }\end{array}$ \\
\hline 4. & Control & $\begin{array}{l}\text { Sulitnya melakukanpengendalian terhadap hasil penilaian yang dilakukan karena masih } \\
\text { dilakukan secara manual. }\end{array}$ \\
\hline 5. & Efficiency & $\begin{array}{l}\text { Prosedur penilaian saat ini kurang efisien karena masih memanfaatkan media kertas dan } \\
\text { aplikasi pengolah data. }\end{array}$ \\
\hline 6. & Service & $\begin{array}{l}\text { Ketidakpuasan karyawan terhadap hasil akhir dari perhitungan penilaian, dikarenakan } \\
\text { perhitungan yang tidak dilakukan secara transparan. }\end{array}$ \\
\hline
\end{tabular}

Analisis kebutuhan dari pengguna serta kebutuhan dari sistem yang akan dibuat digambarkan dengan menggunakan use case diagram yang dapat dilihat pada Gambar 2. 


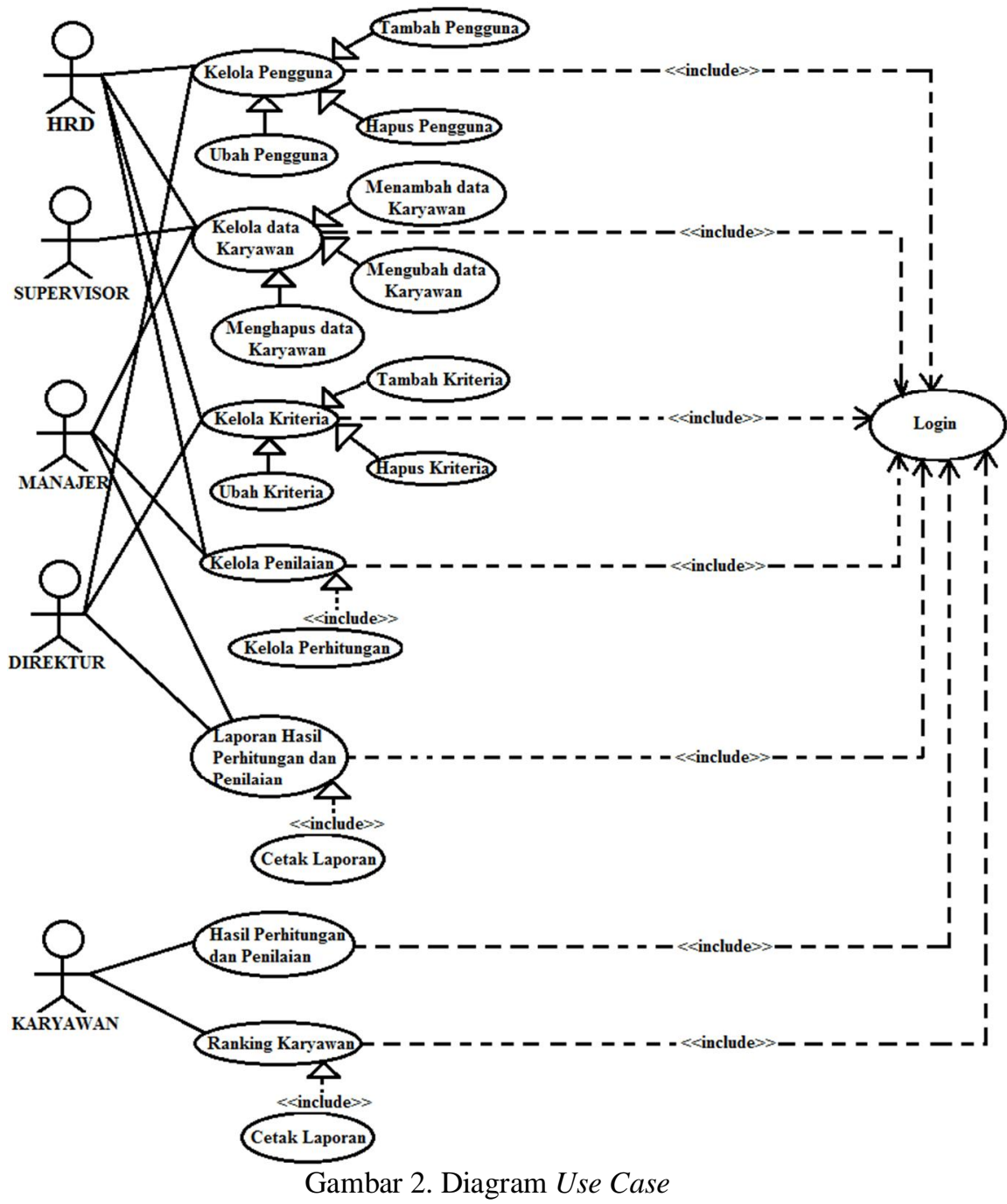

\subsection{Rancangan Sistem}

Pada tahap ini, dilakukan perancangan terhadap sistem yang akan dikembangkan. Rancangan sistem dibuat menggunakan Diagram Dekomposisi, Data Flow Diagram (DFD) dan Entitiy Relationship Diagram (ERD).

\subsubsection{Diagram Dekomposisi}

Diagram Dekomposisi bertujuan untuk memberikan gambaran dari proses yang ada pada sistem dapat dilihat pada Gambar 3. 


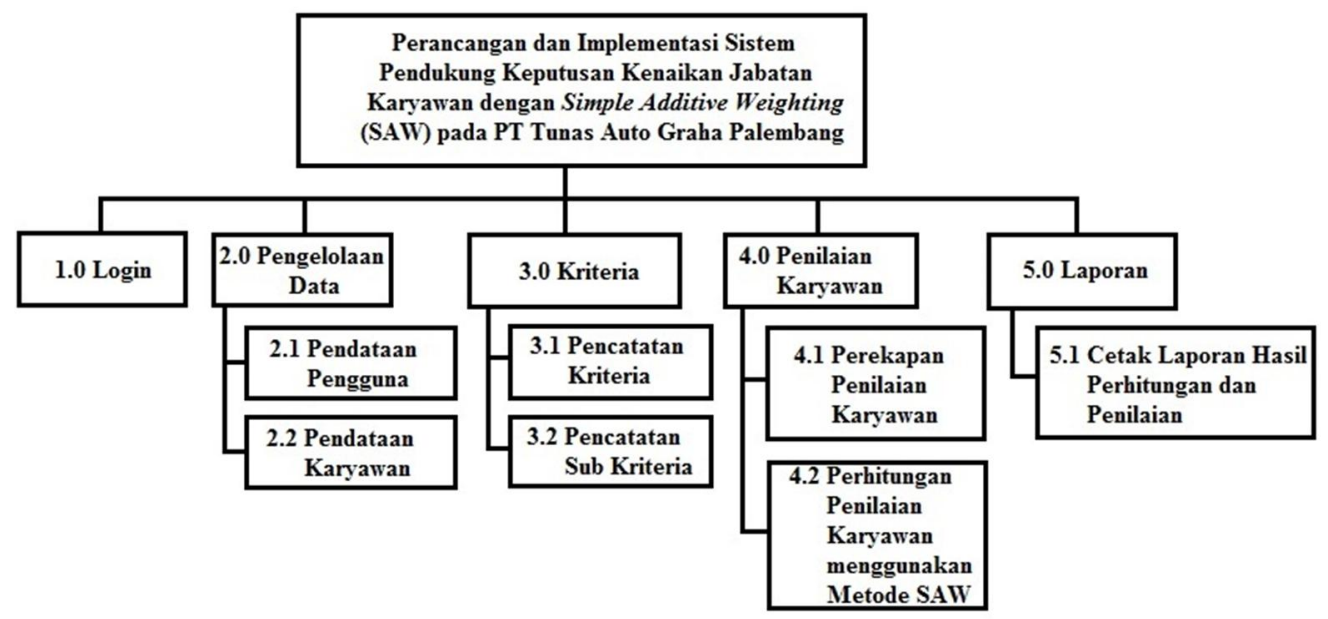

Gambar 3. Diagram Dekomposisi

\subsubsection{Data Flow Diagram (DFD)}

DFD yang dirancang berupa diagram konteks dan DFD level nol yang dapat dilihat pada Gambar 4 dan Gambar 5.

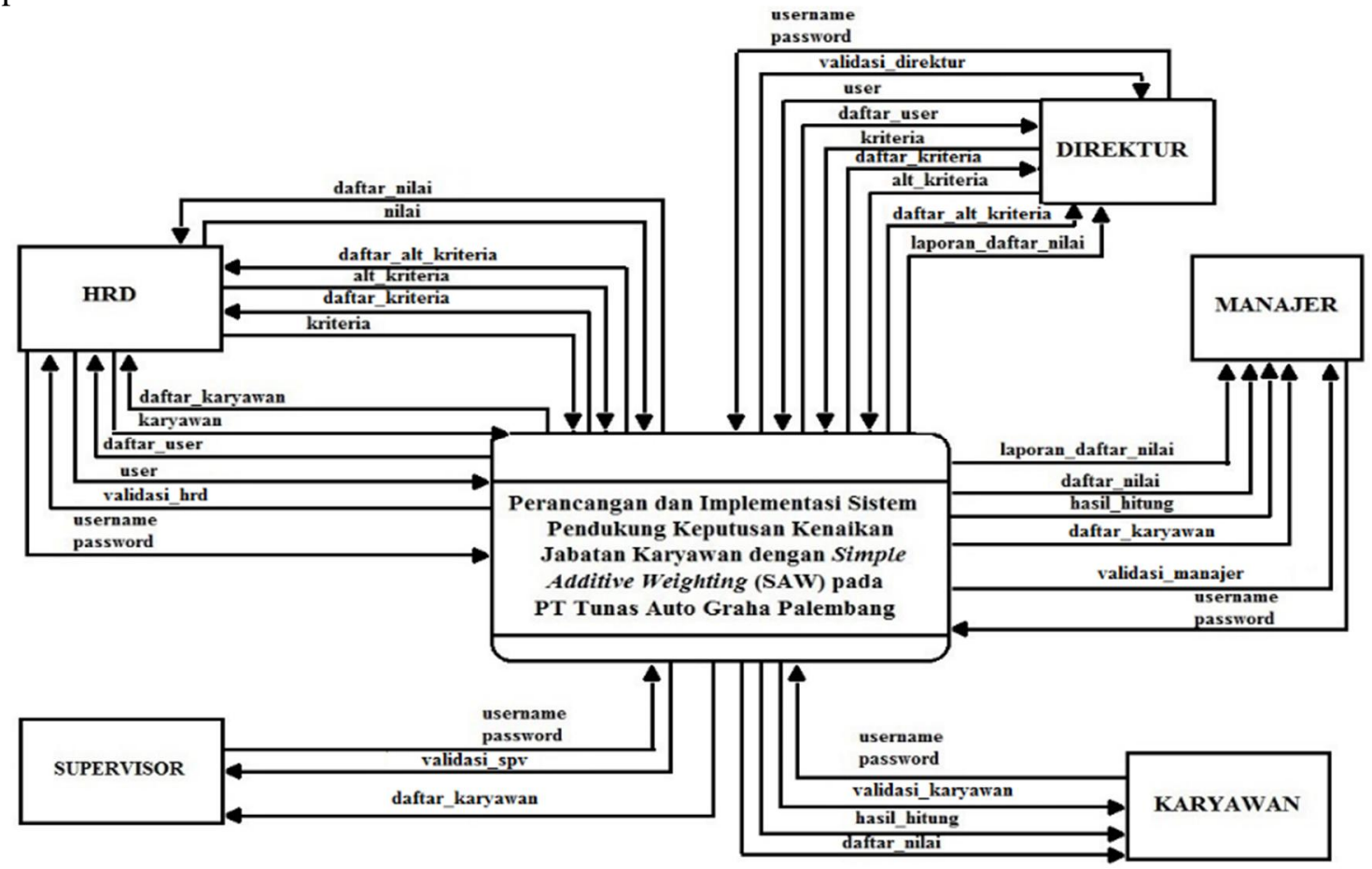

Gambar 4. Diagram Konteks 


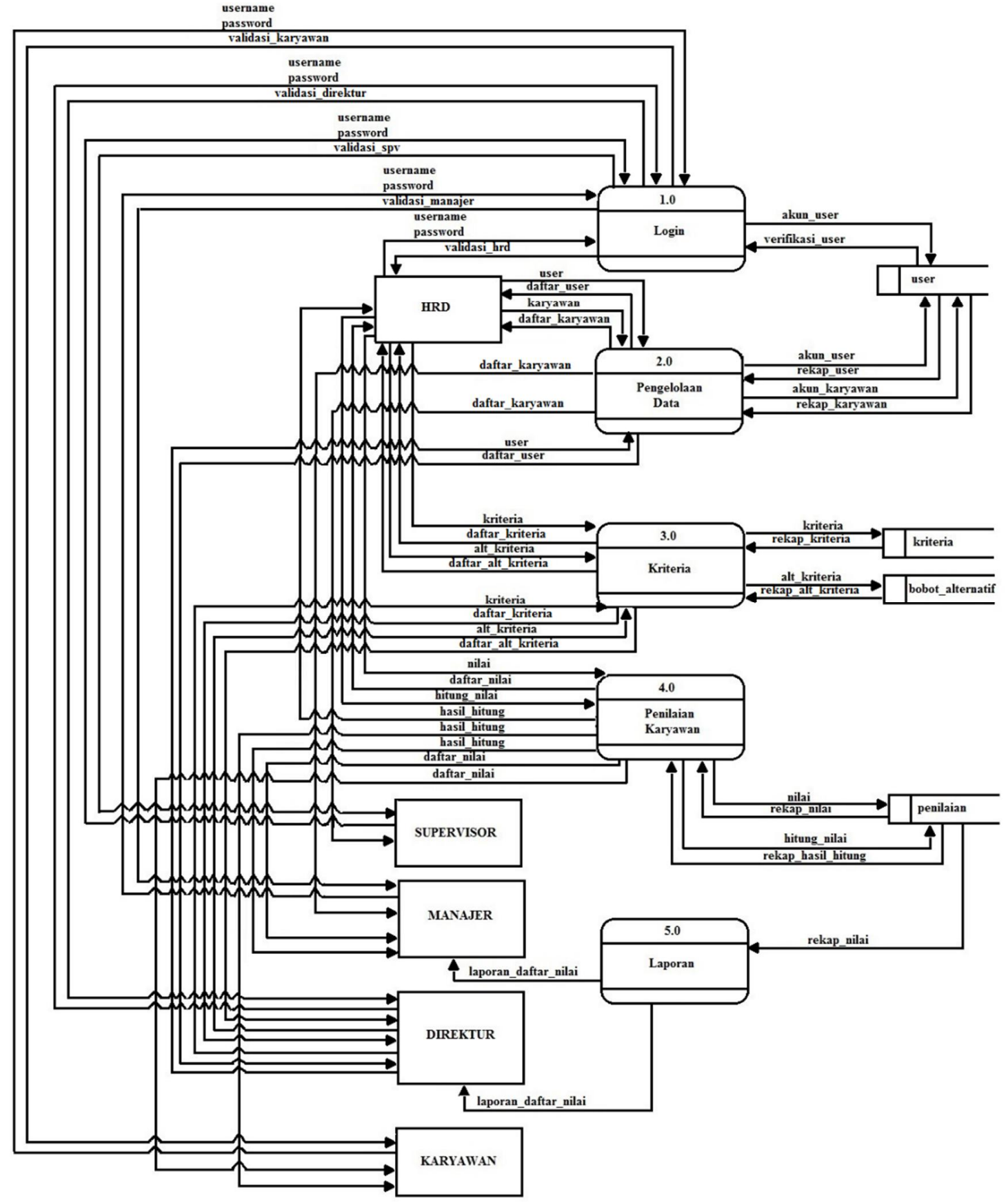

Gambar 5. Data Flow Diagram (DFD)

\subsubsection{Entity Relationship Diagram (ERD)}

ERD yang dirancang pada sistem ini dapat dilihat pada Gambar 6. 


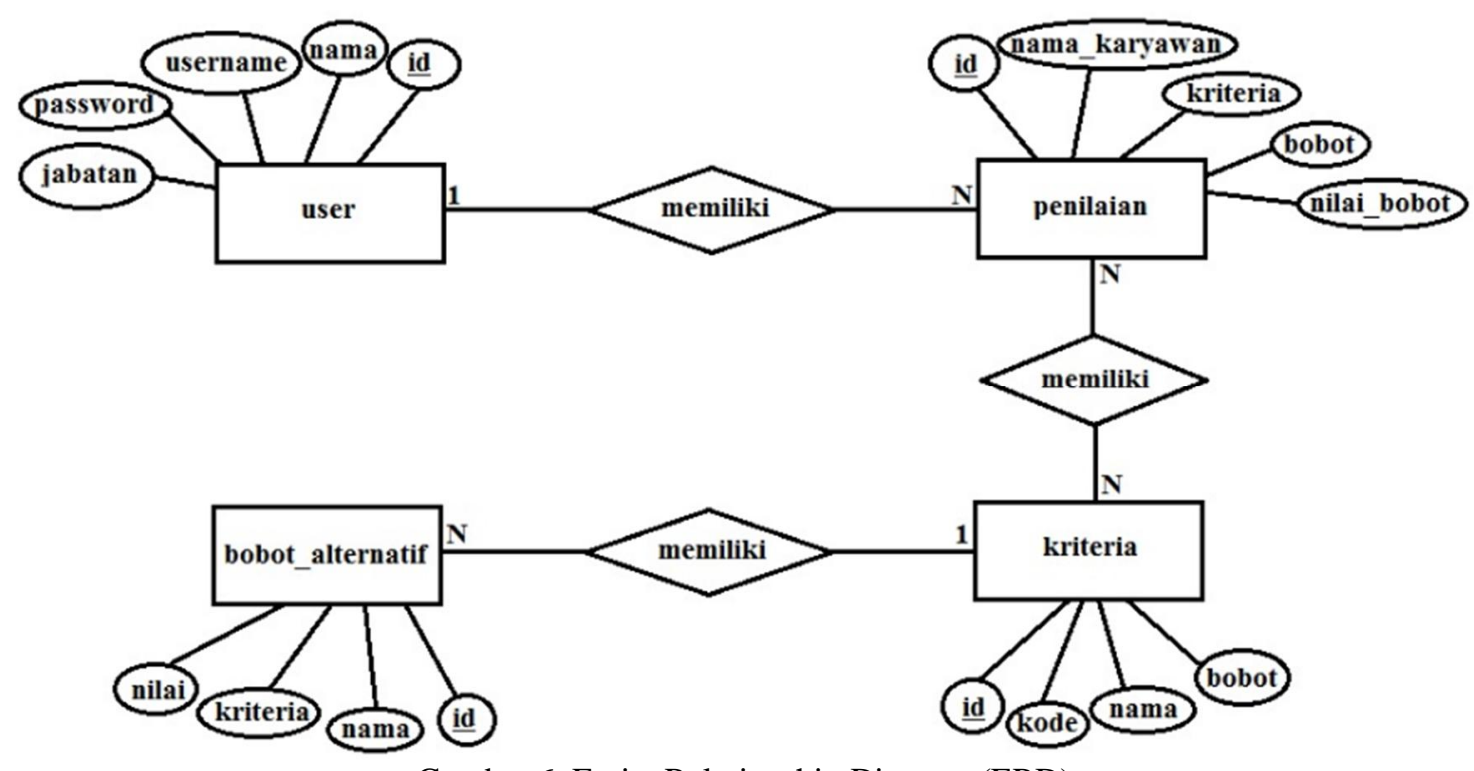

Gambar 6. Entity Relationship Diagram (ERD)

\subsection{Pengembangan sistem}

Setelah merancang sistem, maka tahap selanjutnya adalah melakukan pengembangan sistem atau pengkodean. Sistem ini menggunakan software atau program database server MySQL. Sedangkan aplikasi berbasis website dibuat menggunakan bahasa pemrograman HTML dan php.

\subsection{Metode Simple Additive Weighting (SAW)}

Metode Simple Additive Weighting (SAW) adalah suatu metode yang menjumlahkan bobot dari setiap objek yang tak sama dan memiliki peluang yang sama terhadap setiap kriteria yang dimiliki [1]. Metode Simple Additive Weighting (SAW) memerlukan sebuah proses normalisasi matriks keputusan $(\mathrm{X})$ ke suatu skala yang dapat dilakukan perbandingan terhadap semua rating alternatif yang tersedia. Rumus dari metode SAW adalah sebagai berikut.

$$
r_{i j}=\left\{\begin{array}{rr}
\frac{X_{i j}}{\operatorname{Max} X_{i j}} & \text { JikaJ adalah atribut keuntungan (Benefit) } \\
\frac{\operatorname{Min} X_{i j}}{X_{i j}} & \text { Jika J adalah atribut biaya (Cost) }
\end{array}\right\}
$$

\section{HASIL DAN PEMBAHASAN}

Implementasi merupakan suatu perwujudan atau penerapan dari rancangan sistem yang telah dibuat ke dalam suatu program sehingga fungsi dari masing-masing proses akan terlihat. Pada bagian ini dituangkan hasil dan pembahasan dari sistem yang dibuat.

\subsection{Kriteria Penilaian}

Kriteria yang digunakan pada aplikasi merupakan kriteria yang selama ini diterapkan pada perusahaan, adapun kriteria tersebut adalah sebagai berikut.

1. Absensi, dengan subkriteria Sangat Taat, Taat, dan Tidak Taat.

2. Tanggung Jawab, dengan subkriteria Sangat Bertanggung Jawab, Bertanggung Jawab, Cukup Bertanggung Jawab, Kurang Bertanggung Jawab, dan Tidak Bertanggung Jawab.

3. Kedisiplinan Kerja, dengan subkriteria Sangat Disiplin, Disiplin, dan Tidak Disiplin.

4. Penyelesaian Kerja, dengan subkriteria Cepat, Sedang, dan Lambat.

5. Surat Peringatan, dengan subkriteria Tidak Pernah, 1-3 kali, dan $>3$ kali. 


\subsection{Bobot Kriteria}

Perusahaan menganggap bahwa ada kriteria yang lebih diutamakan dibandingkan kriteria lainnya. Maka dari itu, setiap kriteria yang telah ditentukan diberi bobot sesuai dengan kebijakan pada perusahaan. Bobot kriteria penilaian yang telah ditentukan dapat dilihat pada Tabel 2 .

Tabel 2. Pembobotan Kriteria

\begin{tabular}{|c|c|c|}
\hline Kriteria & Persentase & Bobot \\
\hline Absensi & $10 \%$ & 0.1 \\
\hline Tanggung Jawab & $20 \%$ & 0.2 \\
\hline Kedisiplinan & $10 \%$ & 0.1 \\
\hline Penyelesaian kerja & $30 \%$ & 0.3 \\
\hline Surat Peringatan & $30 \%$ & 0.3 \\
\hline Total & $100 \%$ & 1 \\
\hline
\end{tabular}

\subsection{Rating Kecocokan}

Tiap karyawan dinilai menggunakan kriteria dengan batasan nilai yang juga telah ditentukan yang memiliki bobot nilai antara 0,2 sampai 1 . Rating kecocokan pada setiap kriteria dapat dilihat pada Tabel 3.

Tabel 3. Rating Kecocokan

\begin{tabular}{|c|c|c|c|c|c|}
\hline \multirow[t]{2}{*}{ Kriteria } & \multicolumn{5}{|c|}{ Nilai } \\
\hline & 1 & 0,8 & 0,6 & 0,4 & 0,2 \\
\hline Absensi & Sangat taat & - & Taat & - & Tidak Taat \\
\hline Tanggung Jawab & $\begin{array}{c}\text { Sangat } \\
\text { bertanggung } \\
\text { jawab }\end{array}$ & $\begin{array}{c}\text { Bertanggung } \\
\text { jawab }\end{array}$ & $\begin{array}{c}\text { Cukup bertanggung } \\
\text { jawab }\end{array}$ & $\begin{array}{c}\text { Kurang } \\
\text { bertanggung } \\
\text { jawab }\end{array}$ & $\begin{array}{c}\text { Tidak } \\
\text { bertanggung } \\
\text { jawab }\end{array}$ \\
\hline Kedisiplinan & $\begin{array}{c}\text { Sangat } \\
\text { disiplin }\end{array}$ & - & Disiplin & - & Tidak disiplin \\
\hline Penyelesaian kerja & Cepat & - & Sedang & - & Lambat \\
\hline Surat Peringatan & $>3$ kali & - & 1-3 kali & - & Tidak pernah \\
\hline Total & & & & & \\
\hline
\end{tabular}

\subsection{Relasi Antar Tabel}

Berdasarkan ERD yang telah dirancang, maka dibuatlah tabel basis data dengan relasi yang dapat dilihat pada Gambar 7.

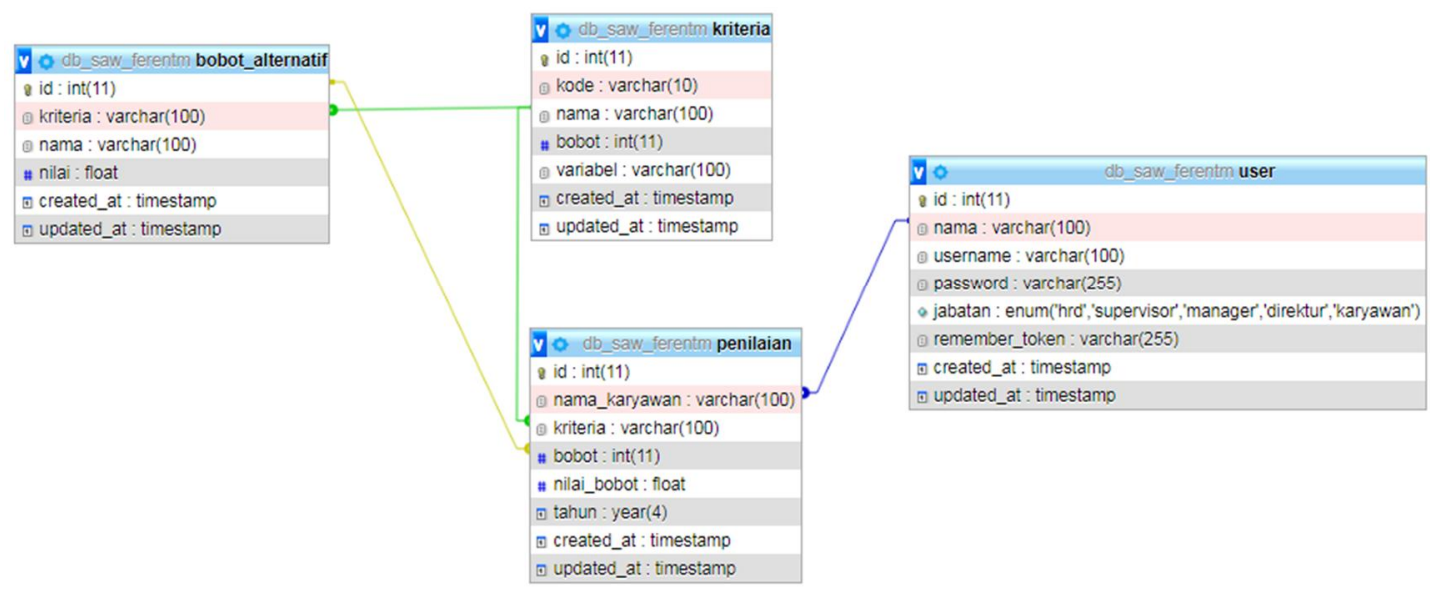

Gambar 7. Relasi Antar Tabel

\subsection{Tampilan Antarmuka Sistem}

\subsubsection{Halaman Login}

Pengguna terlebih dahulu harus memasukkan username dan password jika ingin mengakses website. Setelah itu sistem akan melakukan verifikasi, apabila pengguna terdaftar maka akan masuk ke halaman beranda aplikasi. Adapun bentuk tampilan Halaman Login dapat 
dilihat pada Gambar8.

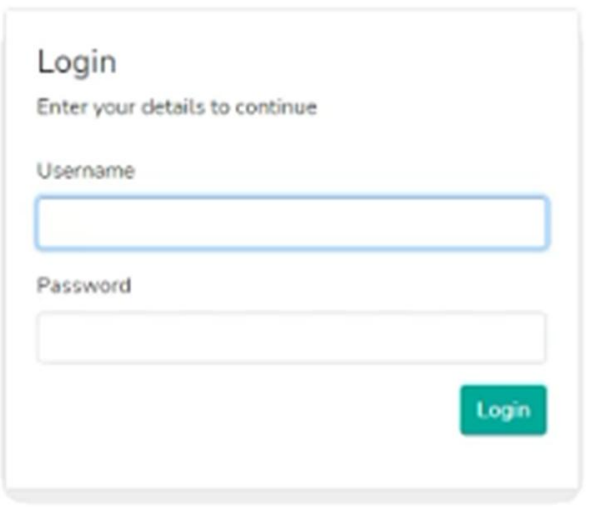

Gambar 8. Halaman Login

\subsubsection{Halaman Kriteria}

Setelah HRD melakukan login, maka akan muncul halaman beranda beserta semua fitur yang dapat digunakan oleh HRD. HRD dapat mengakses halaman kriteria penilaian untuk melakukan perubahan terhadap data kriteria penilaian jika dibutuhkan. Tampilan halaman kriteria dapat dilihat pada Gambar 9.

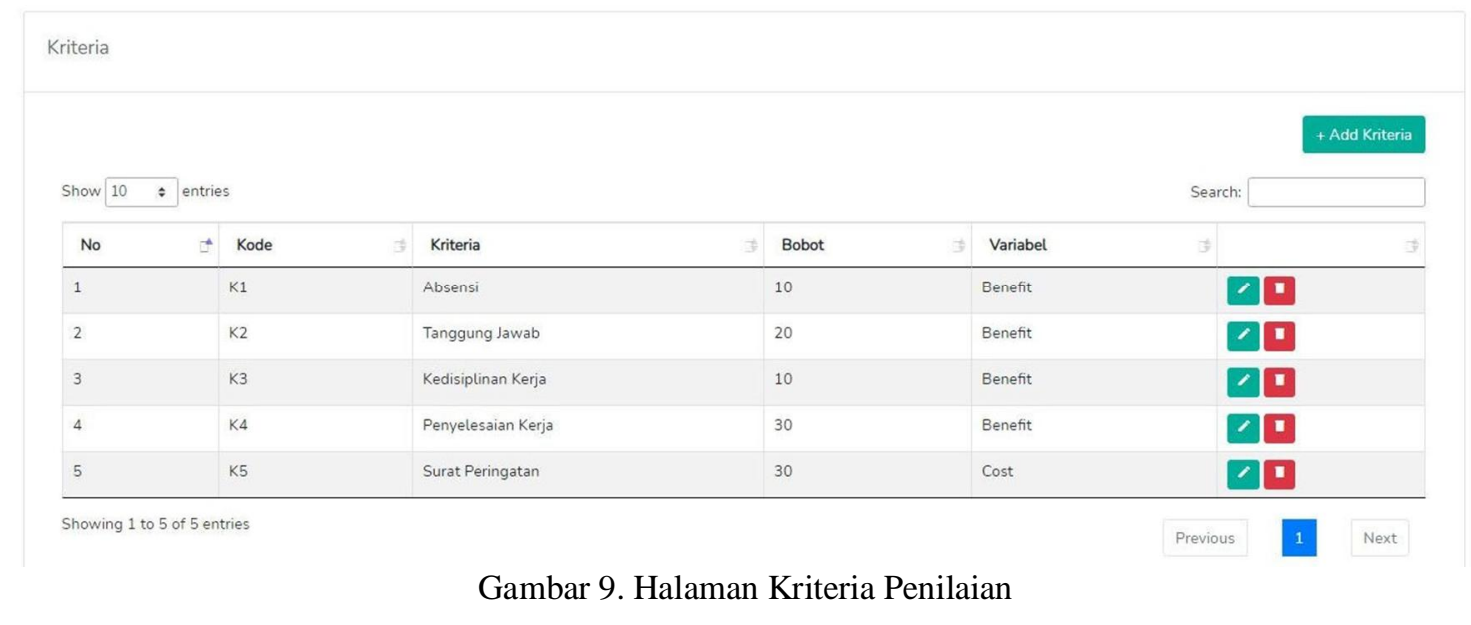

\subsubsection{Halaman Bobot Alternatif}

Pada ini HRD dapat melihat, mencari, mengubah, menambah, dan menghapus subkriteria ataupun nilai dari setiap subkriteria jika dibutuhkan. Adapun bentuk tampilan Halaman Bobot Alternatif dapat dilihat pada Gambar 10. 


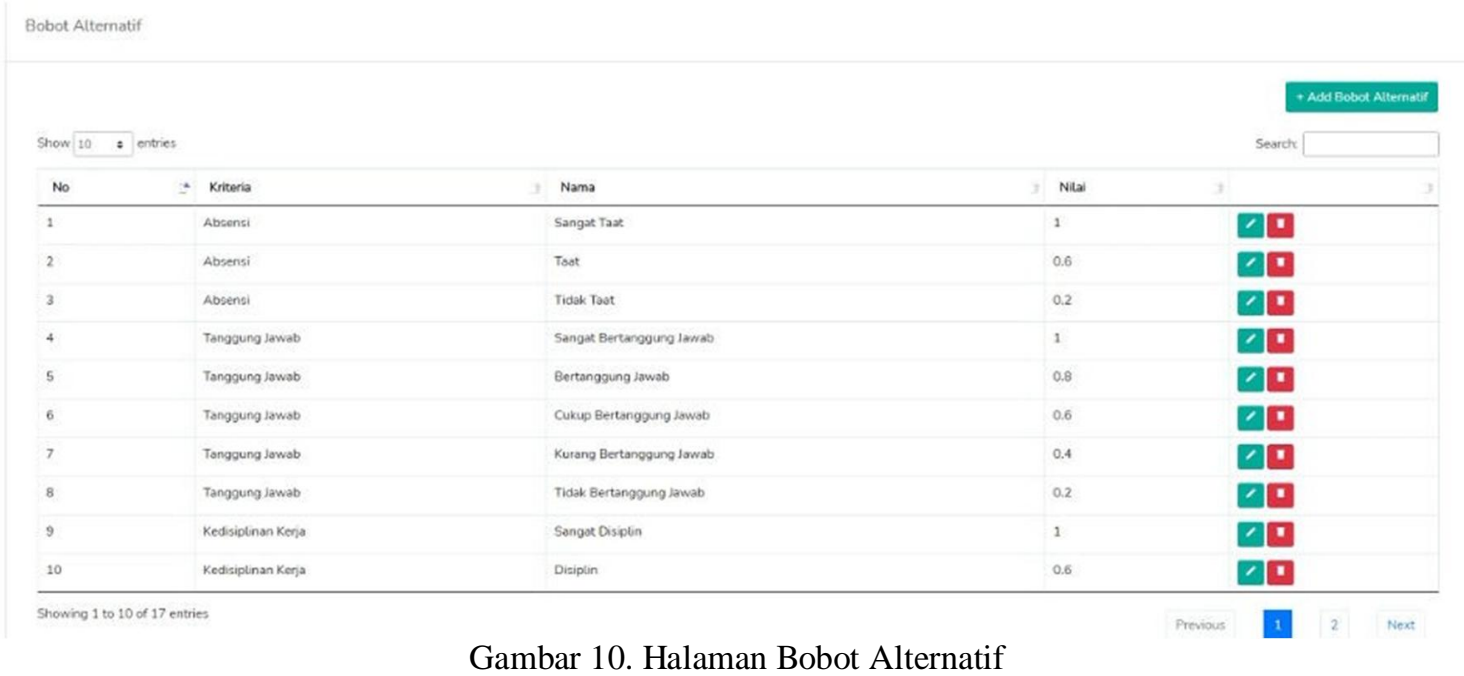

\subsubsection{Halaman Penilaian}

Pada Halaman Penilaian, HRD dapat mencari dan melihat data penilaian setiap tahunnya. HRD juga dapat melakukan perhitungan penilaian karyawan sesuai kriteria yang digunakan oleh perusahaan. Adapun bentuk tampilan Halaman Penilaian dapat dilihat pada Gambar 11.

\begin{tabular}{|c|c|c|c|c|c|c|}
\hline \multicolumn{7}{|l|}{ Penilaian } \\
\hline Tahun: $2020 \mathrm{~V}$ Cari & Tambah Penilaian & & & & & \\
\hline \multicolumn{7}{|c|}{ Data } \\
\hline Nama Karyawan & Absensi & Tanggung Jawab & Kedisiplinan Kerja & Penyelesaian Kerja & Surat Peringatan & \\
\hline Andrico Pratama Putra & 1 & 1 & 1 & 1 & 1 & 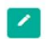 \\
\hline Dyah Ayu Ningsih & 0.6 & 0.4 & 0.6 & 0.6 & 0.2 & 1 \\
\hline Helena Christine Sugandi & 1 & 1 & 1 & 1 & 0.2 & 7 \\
\hline Indra Budiman & 1 & 0.8 & 1 & 0.6 & 1 & - \\
\hline Monica Rahayu & 0.6 & 1 & 0.6 & 0.6 & 1 & - \\
\hline Natalya & 0.6 & 0.6 & 0.6 & 0.6 & 0.6 & $>$ \\
\hline Yogi & 1 & 1 & 0.6 & 1 & 1 & 7 \\
\hline
\end{tabular}

Gambar 11. Halaman Penilaian

\subsubsection{Halaman Perhitungan}

Untuk menjawab masalah transparansi yang tidak dapat ditemukan pada sistem yang lama, maka pada sistem yang baru dibuat agar karyawan dapat melihat hasil perhitungan dari penilaian yang dilakukan oleh HRD. Pada ini, Karyawan dapat mencari dan melihat semua data penilaian setiap tahunnya. Karyawan dapat melihat nilai terhadap semua kriteria yang digunakan oleh perusahaan serta ranking hasil perhitungan terhadap semua karyawan. Adapun bentuk tampilan Halaman Perhitungan dapat dilihat pada Gambar 12. 


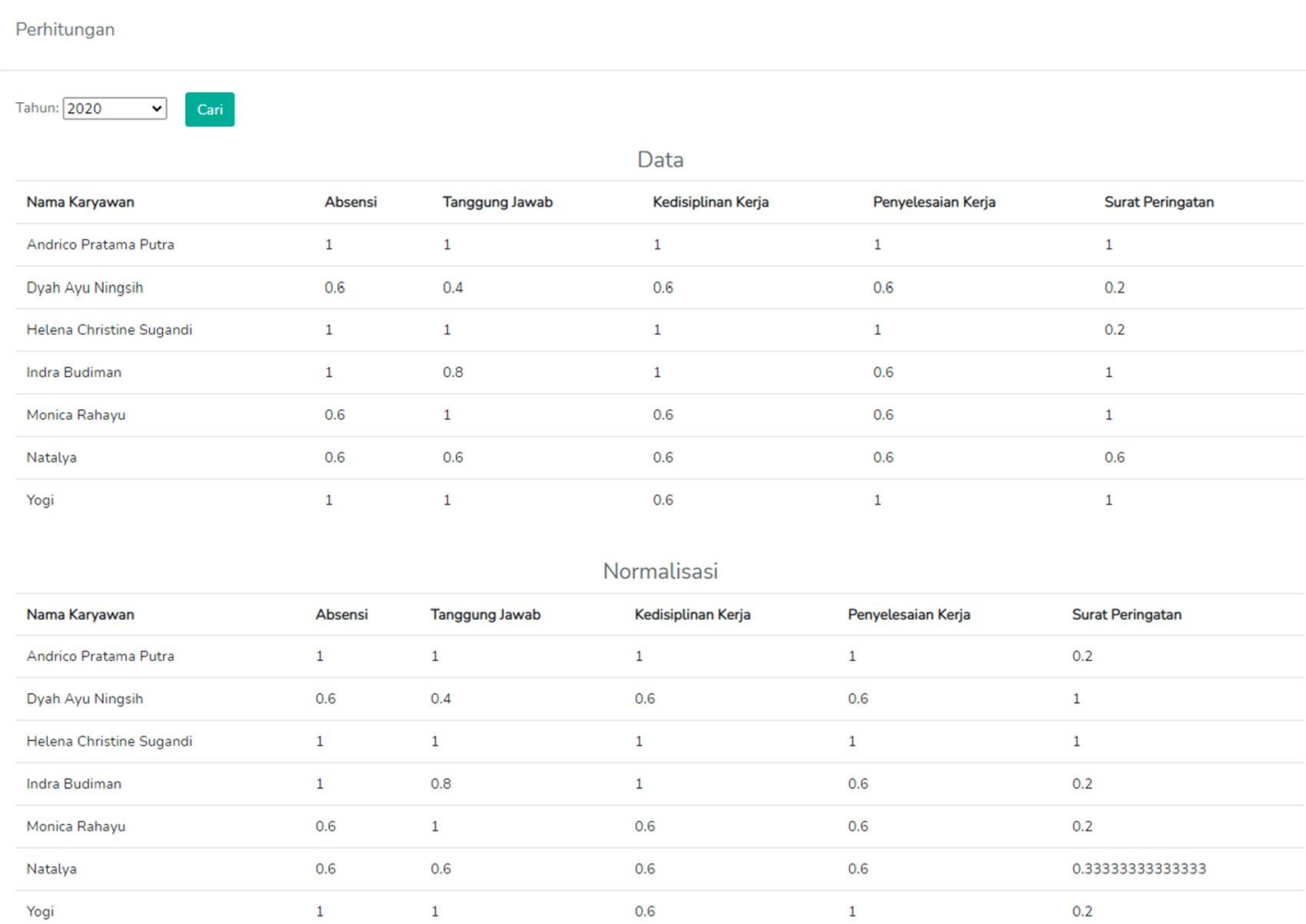

Gambar 12. Halaman Perhitungan

\subsubsection{Halaman Ranking}

Pada Halaman Ranking, Karyawan dapat melihat ranking serta penilaian terhadap semua karyawan sesuai kriteria yang digunakan oleh perusahaan setiap tahunnya. Adapun bentuk tampilan Halaman Ranking dapat dilihat pada Gambar 13.

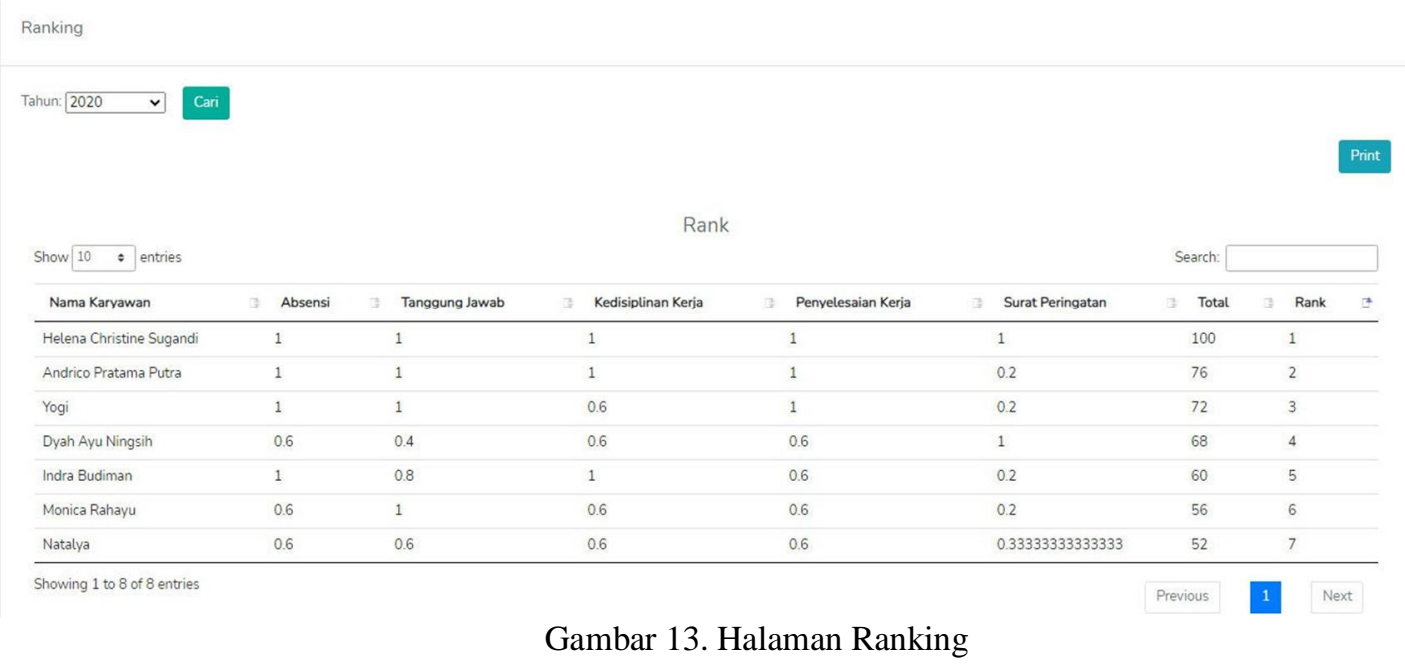

\section{KESIMPULAN DAN SARAN}

Penelitian ini menghasilkan sebuah sistem pendukung keputusan penilaian kinerja karyawan yang dapat digunakan untuk penentuan kenaikan jabatan. Permasalahan terkait transparansi dapat diatasi pada sistem yang dibuat karena karyawan dapat melihat proses perhitungan dan penilaian terhadap semua karyawan yang ada pada perusahaan. Penelitian 
selanjutnya dapat menggunakan metode pendukung keputusan lainnya untuk menyempurnakan sistem pendukung keputusan ini.

\section{DAFTAR PUSTAKA}

[1] Pratiwi, Heny. 2016, Buku Ajar Sistem Pendukung Keputusan, Yogyakarta.

[2] Raymond McLeod dan George P Schell. 2008, Sistem Informasi Manajemen, Jakarta.

[3] Ridlo, Ilham Akhsanu. 2012, Turn Over Karyawan “Kajian Literatur”, Public Health Movement Surabaya.

[4] Asep dan Dodo. 2016, Perancangan Sistem Pendukung Keputusan Dengan Metode SAW Dalam Penentuan Tunjangan Kinerja Pegawai pada Kepolisian Resort Kota Jambi, Jurnal Manajemen Sistem Informasi (MSI), Volume 1 Nomor 1, hal 54-66.

[5] Sahadi, Ardhiansyah, dan T. Husain. 2020, Sistem Pendukung Keputusan Pemilihan Siswa/i Kelas Unggulan Menggunakan Metode AHP dan TOPSIS, Jurnal Teknologi Sistem Informasi, Volume 1 Nomor 2, hal 153-167.

[6] Fateh, Reza, dan Fransiska. 2020, Sistem Pendukung Keputusan Proses DJ Hunt pada PT Radio Prima Elita, Jurnal Teknologi Sistem Informasi, Volume 1 Nomor 1, hal 84-94.

[7] Yulistia, Ricky, dan Rendi. 2020, Sistem Pendukung Keputusan Penerimaan Pegawai Menggunakan Metode AHP (Analytical Hierarchy Process) Hotel RC di Palembang, Jurnal Teknologi Sistem Informasi, Volume 1 Nomor 1, hal 65-72. 